\title{
Social Union, Convergence and Migration
}

\author{
Hans-Werner Sinn \\ Wolfgang Ochel
}

From: Journal of Common Market Studies 41, 2003, pp. 869-896

Electronic reprint 2006-05

June 2006

Department of Economics

University of Munich

Volkswirtschaftliche Fakultät

Ludwig-Maximilians-Universität München

Online at http://epub.ub.uni-muenchen.de 


\title{
Social Union, Convergence and Migration
}

\author{
HANS-WERNER SINN
}

Ifo Institute for Economic Research

WOLFGANG OCHEL

Ifo Institute for Economic Research

\begin{abstract}
The forces of the market and systems competition bring about economic and social convergence in Europe, and there is no need for social policies at the EU level. Social harmonization would distort migration flows and slow down the speed of economic convergence. National welfare states will be threatened by the free migration of people in Europe. The race to the bottom is a serious risk. However, to contain this risk, neither harmonization of welfare payments nor constraints on migration are needed. The adoption of the principle of selectively delayed integration is a better alternative.
\end{abstract}

\section{Introduction}

The convergence of living conditions and of social standards is rightly considered to be one of the great goals of the EU. However, does the desirability of convergence mean that harmonization policies are needed? Should the EU try to speed up social convergence by setting common standards or even by complementing economic and monetary union with a social union right from the beginning of the convergence process?

The answer this article will give is, no. Provided that the EU sets the conditions for economic convergence, social convergence is already being induced by the forces of economic factor price equalization and systems competition among countries that compete for mobile factors of production. Premature social harmonization brought about by centralized policy measures would be detrimental in the sense that it distorts migration flows and slows 
down the speed of real economic convergence. Little can be gained, but much can be lost, by harmonizing social conditions faster than market forces and the forces of systems competition themselves can bring about.

The Convention on the Future of Europe has prepared a Constitution, and European social union is on the agenda. Social protection and social cohesion will become constitutional goals of the EU and, together with the principles of non-discrimination and EU citizenship, these goals could indeed imply premature harmonization. We will discuss this issue below and argue that the consequences for the economic development of Europe would be adverse.

To make this point we will not only advance theoretical arguments, but also analyse the case of German unification. Germany was united by treaties on economic, monetary and social union. We maintain that the economic and monetary unification of Germany alone would have been compatible with the prosperous development and a self-sustained upswing of the former communist part of the country, but that premature social unification may be considered the major reason for the economic disaster that has occurred. East Germany is not catching up and, in fact, the economic gap between the two parts of the country has widened since 1995.

Our position is not that there should never be a social union in Europe, let alone that the European welfare state is useless. There is a powerful argument that free migration may lead to an erosion of the welfare state if migrants are fully included in the host country's welfare system, and we accept that, in principle, this argument is a rationale for the harmonization of welfare measures. Nevertheless, we maintain that, at least during the convergence phase, the principle of delayed integration is a better means of protecting the welfare state against the erosive forces of welfare migration.

Different sorts of social policies affect the basic variables of an economy's transition path, in particular its employment, migration and capital flows. Here we focus on:

1. workplace standards like working conditions or standards of health and safety at work; and

2. replacement incomes, such as social or unemployment assistance.

We first discuss the efficient adjustment path of wages and work-related standards chosen by market forces and the forces of systems competition, following a model of Sinn (2003), and then illustrate the distortions resulting from premature harmonization of social standards and replacement incomes, with reference to German unification and the draft Treaty of the EU Constitution. 


\section{Migration and Natural Convergence}

In 1963, when European borders were still somewhat closed, the per capita income of Portugal was 22 per cent of that of France. In 2000 the Portuguese per capita income was 48 per cent of the French. In 1970, Finland's per capita income was 78 per cent of Germany's, but it is now slightly higher. In 1960, Belgian per capita income was nearly 20 per cent higher than the EU-15 average, but it is now close to the mean. The European countries have been converging. ${ }^{1}$

While these are striking examples, the full convergence picture is shown in Figure $1 .^{2}$ In 1963 the coefficient of variation of per capita GDP values (without Luxembourg) was 0.39. By 2000, it had declined to 0.26. This corresponds to an annual convergence rate of 1.1 per cent which is about half the 2 per cent rate observed elsewhere by Barro and Sala-i-Martin (1995).

In part, convergence results from the forces of factor price equalization; i.e. through knowledge spillovers, commodity trade, capital movements and labour migration. In part, convergence results from the forces of systems competition which induce governments to act competitively so as to maintain the attractiveness of their countries for mobile factors of production. Given that these forces operate in Europe, it is not surprising that convergence has occurred. ${ }^{3}$

However, convergence cannot occur instantaneously and will take decades even under the ideal circumstances of the common market that the EU is providing. This is a crucial point for the evaluation of EU harmonization policies. Convergence takes time because there are costs of adjustment and migration, resulting from the need to transport resources and people, to overcome institutional and logistical constraints, and to compensate for the home preferences that typically characterize Europeans. These costs are less important for knowledge spillovers and commodity trade, but they significantly slow down capital flows and impede the migration of people.

Sluggishness not only characterizes the adjustment of the real economy but also that of government policies. It can be assumed that governments try to find an optimal mix between private and publicly controlled resources at

\footnotetext{
${ }_{1}^{1}$ Convergence did not necessarily coincide with EU membership.

2 The figures are based on current market prices and exchange rates. It might be tempting to express convergence in real terms. However, regardless of common practice, the relative purchasing power parities (PPPs) which are available in official statistics are not suited for this purpose. They are based on national inflation numbers which themselves are calculated on the basis of different national commodity bundles. PPP-based GDP figures would not indicate convergence even if the economies become identical.

${ }^{3}$ Some authors like Rodriguez and Rodrik (1999) find little evidence that open trade policies result in faster convergence. Commodity trade is, however, just one determinant of economic growth, whereas in our understanding convergence is the result of many factors, including free movement of factors of production and technological knowledge.
} 


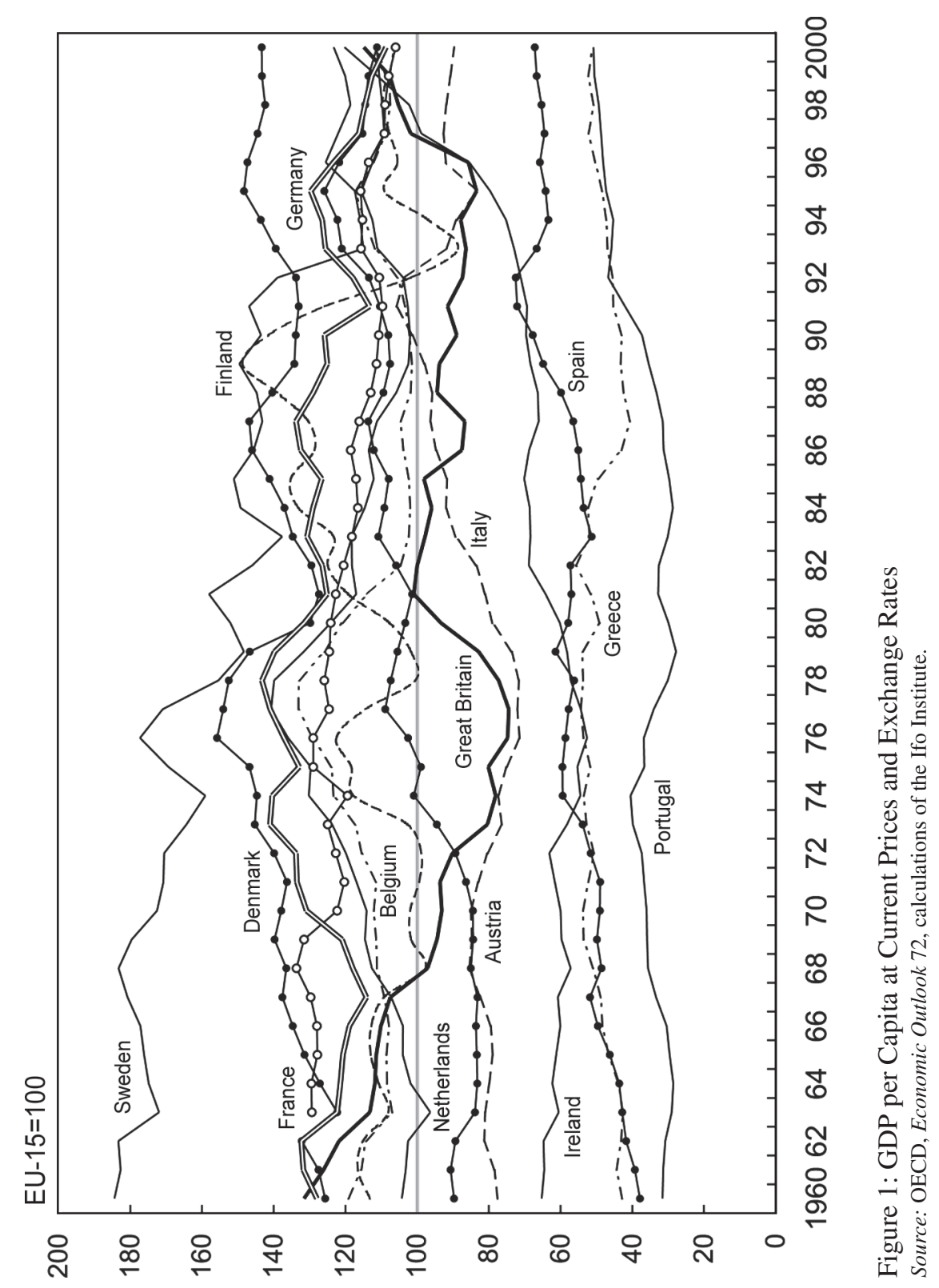


each stage of the adjustment process. Poor countries will find it unwise to try to match the quality of infrastructure of some of the richer countries when people cannot afford the corresponding taxes, and they will not force their firms to satisfy the same labour standards and pay the same social insurance contributions as the more developed countries can afford. Prudent governments will develop social standards in line with the real development of the economies they control.

Figure 2 illustrates the large differences in wages and wage-related social costs across Europe. The differences are particularly large between the new members and the EU-15, but even among the latter there are substantial differences that can partly be attributed to the different times of EU accession. The figure also shows that the differences are not limited to pecuniary wages but are also evident in indirect labour costs, as defined in the notes to the figure. These indirect costs can be seen as wages in kind which generate benefits for employees and costs to firms. Although poorer countries tend to have lower social standards, their mix of direct and indirect labour costs is similar to that of the richer countries.

To understand the nature of the convergence process, two types of migration or adjustment costs that impede flows of labour and capital and slow down convergence should be distinguished. ${ }^{4}$ One is a permanent cost that is a continuing obstacle to operating in another country but does not reduce the migration speed, and one is an initial non-recurring cost that reduces the migration speed, but cannot affect the long-run migration volume. In principle, capital and labour are affected by both types of cost. However, capital seems to be affected much more by the second, and labour much more by the first type, and this is what we assume. In short, we assume that capital is slow but has no home bias, and labour is fast but has a home bias.

In the case of capital, there are costs of acquiring information, learning by doing, overcoming political constraints and, in particular, finding the funds necessary to expand the business. The cost of finance increases progressively with the investment volume, since lenders and owners perceive progressively higher risks. Empirically, most of the equity capital accumulated after the establishment of new firms derives from the retention of profits, and debt grows in proportion to equity. This prevents immediate stock adjustments and implies a gradual growth process instead.

In the case of labour migration, the relevant costs are of a different nature. European migration is, to a large extent, a kind of commuting with lower or higher frequencies which incurs a permanent cost as long as a migrant is

\footnotetext{
${ }^{4}$ We do not consider convergence theories that describe growth processes of countries that do not interact (see Barro and Sala-i-Martin, 1995, chs 1 and 2 ). Such theories make little sense for Europe. European convergence is driven by trade, factor movements and the exchange of knowledge.

(C) Blackwell Publishing Ltd 2003
} 


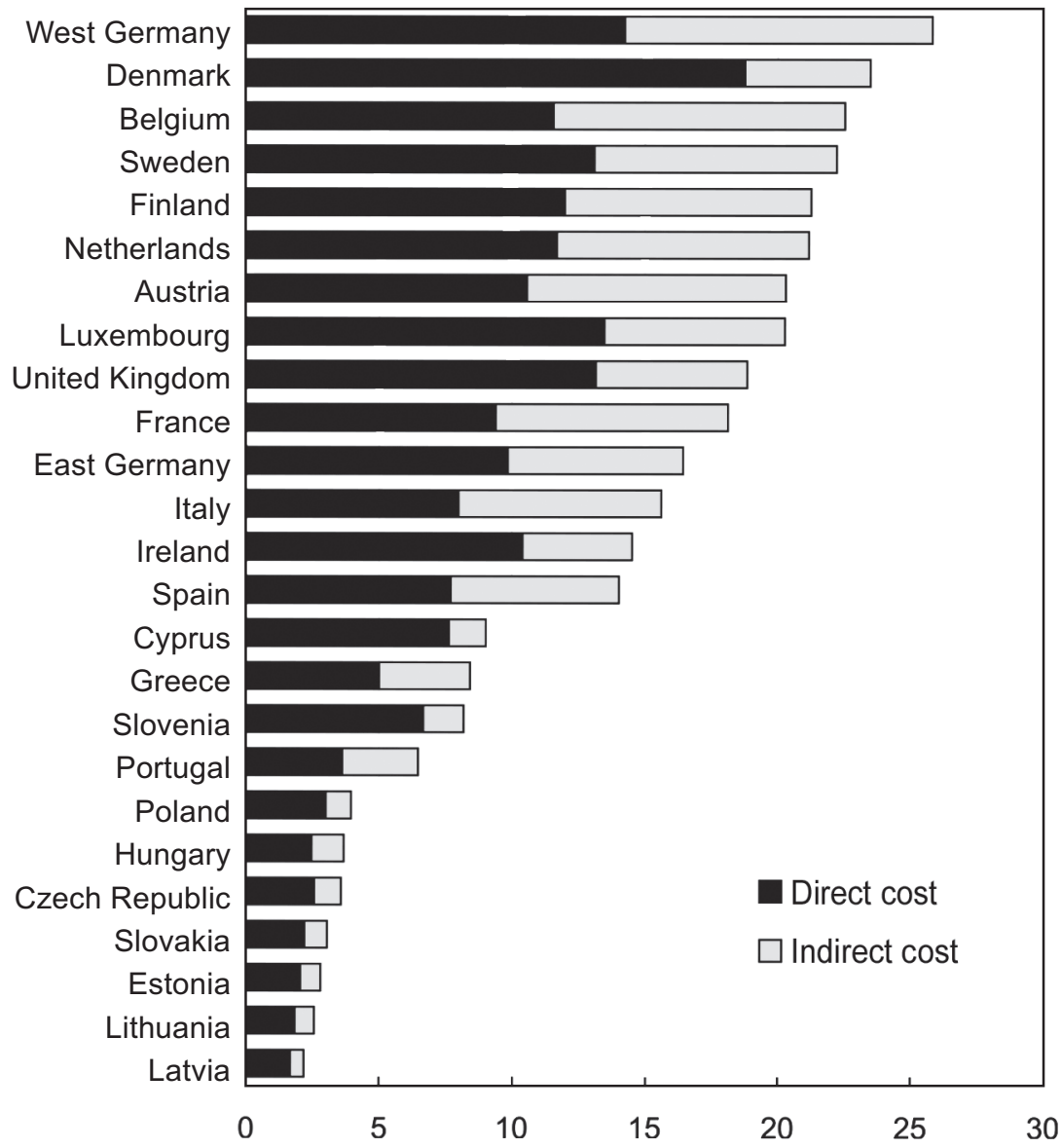

Figure 2: Labour Costs in Manufacturing in EU Countries and EU Accession Countries, 2000 (€ per Working Hour)

Sources: Cologne Institute for Business Research, database 2001; Claire, R. and Paternoster, A. Arbeitskostenerhebung 2000 Kandidatenländer, Eurostat, Statistik kurz gefasst, 2002, pp. 3-23.

Notes: The figure breaks down labour costs into direct and indirect costs according to Eurostat definitions (Schröder, 2000, p. 77). Direct costs are defined as gross wages per hour. They include employees' social security contributions, overtime supplements, shift compensation, regularly paid premia, pay for annual leave and national holidays, etc. Indirect costs consist of employer social insurance contributions, sick pay schemes, expenses for canteens, vocational training, etc. They thus cover those categories of social standards this article considers, but exclude wider aspects such as safety requirements for machinery, dismissal protection rules and constraints on working time. The proportion of indirect to direct wages is higher in the more advanced than in the less-developed countries (for EU accession countries the structure of labour costs refers to the whole economy). 
living abroad..$^{5}$ In addition to the cost of commuting, this type of cost includes the cost of maintaining two residences, the cost of paying higher rents in the host country and the personal disutility of not being able to live in one's home country.

To analyse some important aspects of the convergence process in the presence of such costs, we initially consider a small, less-developed country that joins a large developed area. Smallness means that the conditions in the large area are not strongly affected by the policies of the joining country and can therefore be taken as given. Assume that the small country represents one of the new accession countries of the EU and that the large area is the EU-15. In the accession country, capital intensity and wages are low, in the core area both are high. Commodities, financial capital and technical knowledge are completely mobile across the borders.

Figure 3 illustrates the adjustment process for the accession country in the simplified form of a supply-demand diagram for the labour market. Employment in the accession country is measured on the horizontal axis, the wage rate there is shown on the vertical axis. The initial labour demand curve of the accession country's employers is represented by DD and the labour supply curve is represented by SS. 6

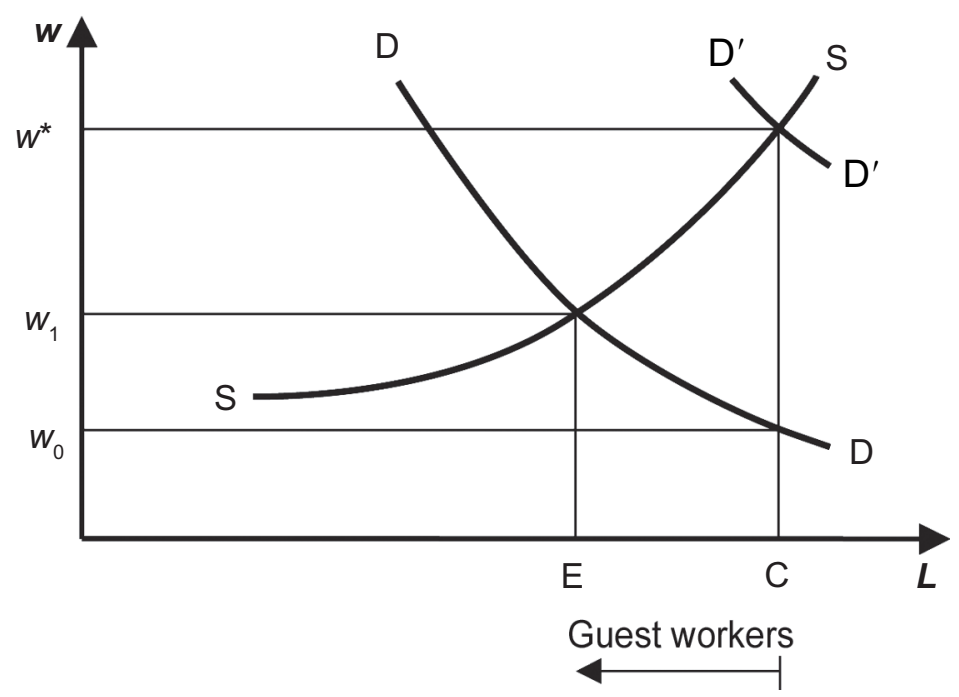

Figure 3: Adjustments in the Labour Market

\footnotetext{
${ }^{5}$ Even someone who emigrates for a long period of time can in this sense be seen as a commuter if he or she regularly returns home to see family and friends.

${ }^{6}$ Related models can be found in Sinn and Sinn (1992, ch. 5) and Sinn (2001). 
The labour demand curve is the usual marginal product curve. It is derived by ranking potential jobs in the accession country by the value added that they generate. If the wage is lower than the value added, it is profitable for a firm to establish the job and employ a worker. Given the heterogeneous set of blueprints for potential jobs, the number of workers who can profitably be employed is obviously the larger the lower the wage rate. The demand curve is drawn for a given aggregate stock of capital. It will shift outwards over time if the stock of capital grows. As the specific adjustment cost we assumed excludes jumps in the size of the capital stock, the position of the curve is fixed at any given point in time, regardless of the volume of investment. However, the volume of investment determines the speed at which the curve moves outwards over time.

The supply curve is derived by ranking heterogeneous workers according to their 'stay-put' wages. The 'stay-put' wage is the subjective wage at which an inhabitant of the accession country is indifferent between staying at home and moving to the core region. The 'stay-put' wage of a particular inhabitant of the accession country equals the wage in the core area, $w^{*}$, which is also taken to equal the marginal product of labour in the core area minus the migrant's subjective and objective migration cost. Ranking the heterogeneous inhabitants of the accession country by the size of these costs generates the internal supply curve of the labour market of the accession country. We assume that a person migrates if his cost falls short of the wage differential between the core area and the accession country, and stays in his home country if it exceeds this differential. ${ }^{7}$ As the number of people whose cost is higher than the wage differential, and who therefore do not move, is the larger the smaller the wage differential, the supply curve is upward sloping.

Suppose now that accession takes place at time 0 and the previously closed borders are opened. This will induce inverse cross-border investment and migration flows between the core area and the accession country, but for the time being the labour demand curve of the accession country will not be affected. Part of the workforce of the accession country now migrates rapidly to the core area, ${ }^{8}$ and the increased scarcity of labour in the accession country raises the wage rate above its previous level $w_{0}$. A temporary equilibrium is found in the labour market of the accession country where supply equals demand. The wage rate therefore rises to $w_{1}$, and the workers whose jobs are destroyed by this rise, $\mathrm{CE}$, migrate to the core area.

\footnotetext{
${ }^{7}$ Admittedly, this is a crude simplification of the set of potential motives. See Schmidt (1994) for a thorough empirical investigation. However, the simplification is sufficient to make our point about the cost of premature harmonization, and it seems to fit the type of migration that we observe in Europe which differs substantially from the more permanent type of immigration that seems to characterise the US.

${ }^{8}$ In Germany, practically all the labour migration took place in the first two years after unification, while the annual flow of capital to east Germany has been very persistent since the time of unification.
} 
The temporary equilibrium is efficient. Migration replaces the low value added that migrants could have produced in the accession country with the high value added they can produce in the core area, which equals $w^{*}$, and all of those whose net increase in value added is above the migration cost migrate while all others stay in the accession country. The 'invisible hand' generates an allocation of the workforce to the two regions that maximizes the joint GNP net of migration costs that the accession country's population is able to generate at home and abroad. It is given by the area under the demand and supply curves. ${ }^{9}$

Over time, the labour demand curve in the accession country will shift outward since the comparatively low wage rate $w_{1}$ attracts capital from the core area, and for each position of the labour demand curve there is a new temporary equilibrium with, respectively, a higher wage rate and a smaller stock of migrants. Migrants return to their home country as its economy catches up and offers an increasingly attractive wage level. The process comes to a halt when wages in the core area and the accession country are equal and the former workforce is reinstalled in the new member country. This is symbolized by curve $\mathrm{D}^{\prime} \mathrm{D}^{\prime}$ in the figure.

Competition implies full economic convergence. It not only determines the efficient temporary equilibrium, but also the right speed of the adjustment process, balancing the unavoidable adjustment costs with the preference for fast convergence. ${ }^{10}$ The basic EU policies needed for this process to come about include the creation of a common market and a monetary union, policies already adopted.

The return migration pattern predicted by our model fits the reality of past EU migrations. A substantial proportion of southern European guest workers, recruited to work in Germany from the late 1950s through to the early 1970s, have returned to their home countries. Observations of immigrants (from Italy, Greece, Spain, former Yugoslavia, and Turkey) extracted from the German Socio-economic Panel demonstrate that, of 3010 immigrants surveyed in 1984, 765 ( 25 per cent) returned between 1984 and 1997 (Constant and Massey, 2002 , p. 13). If there were no replacement migration to compensate for some of the return migration, this would correspond to a convergence speed of 2.1 per cent per year which is even higher than the economic convergence speed which we showed above to be in the order of 1.1 per cent. If half of the observed return migration were replaced by new emigrants from the accession country, the return migration figure would roughly fit the actual European rate of convergence.

\footnotetext{
${ }^{9}$ The model abstracts from migration externalities.

${ }^{10}$ The formal proof can be found in Sinn (2003, ch. 4).

(c) Blackwell Publishing Ltd 2003
} 


\section{Harmonizing Social Standards}

Let us now extend the analysis to social standards. Directives and other types of regulation bearing on working conditions constitute the main instrument of EU social policy. As explained above, social standards can be seen as wages in kind that generate utility for the workers and incur costs for firms. As both the direct wage and the wage in kind are to be paid from the same marginal product of labour, it is in the interests of workers that these two components are optimally mixed so that their utility is maximized at any given level of the overall wage cost.

In many cases it can be assumed that this optimal mix is found by the firms themselves, for a competitive firm that finds a better mix than its rivals will attract more workers, or will be able to cut its wage cost. In other cases, asymmetric information problems might legitimate a national policy of setting social standards. However, it is hard to see why an international body like the EU should be better able to fix social standards than national governments themselves. A national government will have all the incentives and all the information needed to come up with an optimal policy, and there is no advantage to the supranational level. In particular, a premature international harmonization of social standards at a level that is appropriate for the core area will definitely be sub-optimal for the accession country, for one size cannot fit all.

To analyse the distortion, consider two alternative definitions of the wage rate:

1. the 'wage cost' which is the sum of the direct and indirect cost of labour to the firm; and

2. the 'equivalent wage' which is the monetary equivalent of the mix between the direct and indirect wage components as judged by the workers.

Figure 3 can be taken to refer to the case of optimal mixes in the core area and the accession country where the respective wage cost equals the equivalent wage. By way of contrast, Figure 4 represents the case of a sub-optimal mix in the accession country resulting from premature harmonization. The core area imposes a standard optimal under its economic conditions on the economy of the accession country. The accession country is forced to have a sub-optimal mix between the direct wage and the wage in kind. A sub-optimal mix means less utility for any given level of the wage cost: a wedge is driven between the wage cost and the equivalent wage. The demand for labour depends on the wage cost, and the supply of labour depends on the equivalent wage, but both are no longer equal. As shown in the figure, the equilibrium 


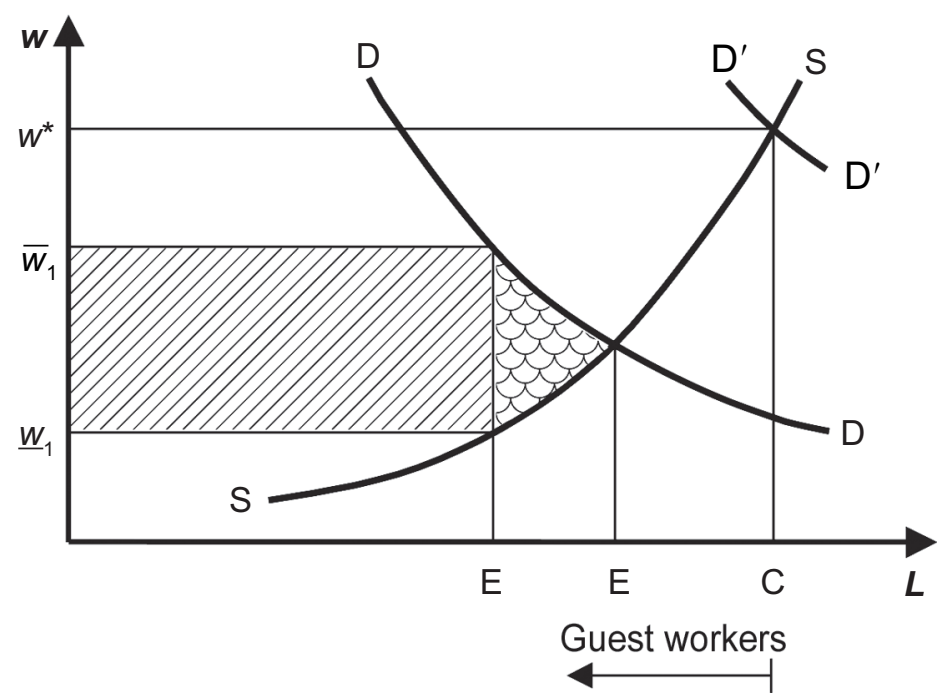

Figure 4: Premature Harmonization of Social Standards

employment in the accession country shrinks by FE because more people migrate to the core area. Workers are able to shift some, but not all of the cost of the sub-optimal mix to firms. The wage cost to firms rises to $\bar{w}_{1}$ and the equivalent wage of the workers falls to $\underline{w}_{1}$.

The harmonization policy is clearly inefficient. It involves two types of welfare losses which are represented by the shaded areas in Figure 4. The dotted triangle measures the deadweight loss from a sub-optimal allocation of the population to the two regions. The shaded rectangle measures the deadweight loss associated with the sub-optimal mix as such which has to be borne by all workers in the accession country.

The welfare cost illustrated in Figure 4 is of a static nature. It is the cost at one particular point in time, given the then available stock of capital. There is an additional cost resulting from the fact that, with any given stock of capital, the wage rate is higher and the incentive to invest in the accession country is lower. Thus, convergence is slower than in the undistorted case. Nevertheless, there continues to be capital accumulation as long as the wage cost in the accession country remains below the cost of the core area. As the wage cost in the accession country approaches that in the core area, the distortion resulting from the premature imposition of the social standards of the core area diminishes. Thus, the labour demand curve continues to shift to the right, albeit at a lower speed, and it converges as before to the position $\mathrm{D}^{\prime} \mathrm{D}^{\prime}$. In the end, when convergence is completed, the distortion disappears. 
In short, the policy of premature harmonization will not affect the steady state allocation of labour, but it will imply excessive migration, will impose a deadweight loss on the total workforce of the accession country during the convergence process and will slow down the convergence process.

This does have implications for the evaluation of EU policy. Thus far, EU social policy has concentrated on working conditions, culminating in the Social Chapter of the Treaty of the EU signed at Amsterdam in 1997 by all EU member countries (including the UK). The Social Chapter extended qualified majority voting to several new areas including working conditions, information and consultation of employees, as well as gender equality in the labour market. Majority voting facilitated the ratification of binding directives in the form of minimum requirements (Bean et al., 1998, pp. 1-9; Feldmann, 1999; Kleinman, 2002, ch. 4). ${ }^{11}$

However, the EU countries seem to have understood that fixing uniform European social standards is hampered by the diversity of national economic conditions and social preferences. Thus the 2000 EU summit in Lisbon opted for an additional governing mode, the 'open method of co-ordination'. This leaves effective social policy choices to the national level, but tries to improve the process by promoting common objectives and common indicators, and by comparative evaluations of national policy performance (Scharpf, 2002). This is exactly what the above considerations would suggest because it effectively avoids premature harmonization.

One of the arguments often presented in favour of harmonization of social standards is to prevent social dumping, i.e. unfair competition which neglects the welfare of workers. It is argued that unfavourable working conditions in the less-developed EU countries are partly the result of an unfair policy which is carried out intentionally, or at least tolerated, by national governments. These governments, it is maintained, stick to low social standards and do not care about low wages because they know that they result in competitive advantages for the domestic industries.

The accusation of social dumping is made particularly by business representatives and union leaders of the more advanced countries, and they seek to influence the EU decision-making process by lobbying for early harmonization. They can also make use of Article 139 (2) of the 1997 Treaty Establishing the European Community which provides them with the right to take the initiative in formulating social standards which, by resolutions of the Council of Ministers, can become internationally binding rules (Belke and Hebler, 2002, p. 319). In the light of the above discussion, these legal provisions are

\footnotetext{
${ }^{11}$ EU citizenship has not yet been very effective in promoting a European social union. It remains to be seen if its inclusion in the EU Constitutional Treaty will change its importance (Closa, 1998; Kleinman, 2002, ch. 8).

(c) Blackwell Publishing Ltd 2003
} 
dubious, to say the least. They originate from protectionist ideas framed in terms of 'fair competition' among European firms, but constitute severe obstacles to the competitive forces that determine an efficient convergence path.

Differences in wages and working conditions reflect transitional phenomena during convergence that result from natural and non-surmountable frictions in the international allocation of capital and labour. Abstracting from such frictions is appropriate for a long-run analysis. Indeed, with an unrestricted exchange of goods, free choice of work place and free capital movements, the current differences in overall wage costs and working conditions illustrated in Figure 2 cannot be maintained in the long term. However, because of the frictions, factor price equalization cannot, and should not, come about overnight but will take decades to be achieved. Slow adjustment of social standards is a natural feature of a transformation process, and premature harmonization can only be detrimental.

\section{Harmonizing Wage Replacement Incomes}

We turn now to the harmonization of replacement incomes such as social assistance, unemployment benefits or early retirement schemes. Such harmonization has not yet been adopted by the EU. According to the White Paper on European Social Policy (Commission, 1994) the EU should only support Member States by spreading best practices. However, in reality there is substantial pressure towards convergence of social policies across EU countries (Kleinman, 2002, p. 97) and, what is more, Article I 13 in connection with Article III 104 of the draft of the new EU Constitution explicitly gives the EU the right to harmonize by way of setting minimum standards.

Replacement incomes are reservation wages; they create a floor for wages at which the eligible are willing to work. Since the productivity of a person also sets the maximum wage an employer is willing to pay, there will be no job for this person if the replacement income exceeds his productivity. In the core countries, the actual level of the replacement incomes may be manageable, as long as replacement incomes are sufficiently far below the market wage, but harmonization at a level appropriate for the core that is binding for the accession countries is likely to result in mass unemployment there.

Normally, mass unemployment will lead to emigration. However, mass unemployment created by high replacement incomes will not have this effect, because replacement incomes paid by the state are stay-put premia. They destroy the incentive to look for jobs in the EU core countries if the difference between the core countries' wage and the accession country's replacement income is less than the cost of migration. The higher the replacement income, the smaller is the number of people willing to look for jobs in the core area. 


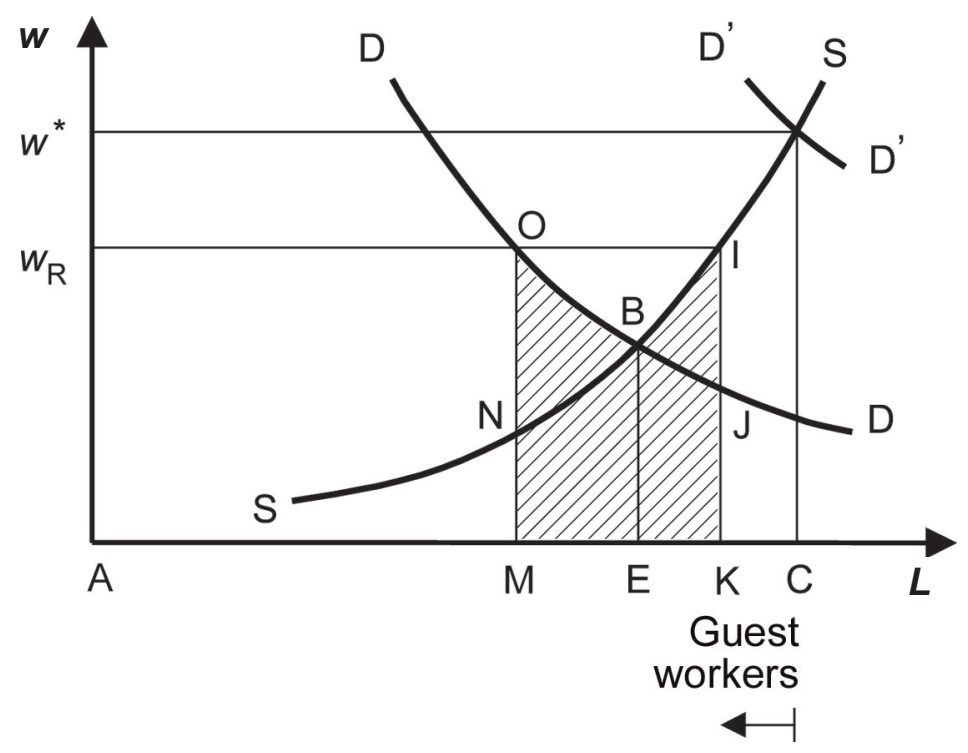

Figure 5: Harmonizing Replacement Incomes

Figure 5 illustrates this. The replacement income $w_{\mathrm{R}}$ limits the number of migrants to $\mathrm{KC}$ and the number of jobs to AM. Accordingly it results in unemployment MK. The allocation of the accession country's workforce is extremely inefficient. As too many jobs are destroyed at home, domestic output falls short of the optimum by OBEM. And as too few people migrate to the core area, foreign output net of migration costs falls short of the optimum by BIKE. The total welfare loss is the sum of the shaded areas, i.e. OBIKM. The national product of the EU, net of migration costs, would rise by this amount if the natural convergence strategy were used instead of harmonizing replacement incomes.

The policy will also be very costly for the government since the unemployed will have to be financed. In the figure, the area OIKM represents the budget cost to the government. In all likelihood, this budget cost will result in a demand for huge EU equalization and cohesion programmes that generate massive flows of funds from the core countries to the accession country.

All of this is extremely inefficient. The budget cost of paying the replacement incomes exceeds the welfare cost by the triangle OIB. As readers can easily verify for themselves, this triangle shrinks to zero relative to the size of the budget cost as the replacement income per individual is reduced to the level BE where it would no longer be binding. It follows that the first step towards harmonization of replacement incomes that effectively constrains the 
accession country's economy involves a welfare cost equal to the budget cost of paying the replacement incomes.

To summarize: the harmonization of minimum replacement incomes such as social assistance will have two damaging economic effects. It will produce unemployment in the accession countries and it will prevent useful and efficient migration which otherwise would have occurred. Even those whose migration would increase European GDP by more than the cost of migration stay in the accession countries. The fiscal cost resulting from unemployment will require compensating fiscal transfers from core countries. Any small EU fiscal equalization programme that is used to finance initial steps towards harmonization of welfare payments will incur welfare losses that are equal in size to the volume of this programme.

To get a feeling for the empirical importance of the problem, Table 1 compares the level of German social assistance with the wage incomes in the eastern EU accession countries. Monthly gross wage earnings of an average production worker range from $€ 267$ in the Slovak Republic to $€ 469$ in Poland, and the corresponding wage incomes net of all taxes and social security contributions range from $€ 202$ to $€ 417$ depending on family status and country (for the year 2000). These incomes are far less than west German social assistance, which amounts to $€ 614$ for single persons and $€ 1508$ for married couples with two children.

German social assistance payments to single persons are 2-3 times the average net wage in these four east European accession countries, and German social assistance payments to families with two children are 4-6 times

Table 1: Net Wage Earnings in Eastern EU Accession Countries and the Level of German Social Assistance (2000)

\begin{tabular}{lccc}
\hline & $\begin{array}{c}\text { Monthly Gross } \\
\text { Wage Earnings } \\
€^{a}\end{array}$ & $\begin{array}{c}\text { Monthly Net } \\
\text { Wage Earnings, } \\
\text { Single Person } \\
€^{a}\end{array}$ & $\begin{array}{c}\text { Monthly Net } \\
\text { Wage Earnings, } \\
\text { one Earner Couple } \\
\text { with Two Children } \\
€^{a}\end{array}$ \\
\hline Poland & & 322 & 349 \\
Czech Republic & 415 & 317 & 417 \\
Slovak Republic & 267 & 214 & 260 \\
Hungary & 300 & 202 & 256 \\
West Germany & 3185 & 1541 & 2135 \\
West German social & & 614 & 1508 \\
assistance & & & \\
\hline
\end{tabular}

Sources: OECD (2002); Sinn et al. (2002), p. 10.

Note: ${ }^{a}$ Average production worker.

c) Blackwell Publishing Ltd 2003 
the eastern net wage. These differences are so huge that social harmonization on the German level would lead to serious economic problems with mass unemployment in the east.

\section{Lessons from German Unification and the Italian Mezzogiorno}

\section{German Unification}

German unification exemplifies the problems resulting from premature harmonization of social replacement incomes and social standards. Germany had to learn painfully how expensive it is to carry out a policy of social unification against market forces.

In anticipation of a prosperous future, a policy of equalization of social conditions was implemented from the beginning. In 2001 the regular rate of social assistance to the poor reached 96.5 per cent of the west German level (Boss, 2001, p. 15) and, thanks to various forms of social transfers, household net incomes stood at about 80 per cent. Pensions per recipient are 110 per cent of the western level (Nierhaus, 1999). These figures are expressed in nominal terms. Allowing for differing price levels, they would all be about 10 percentage points higher.

Western standards on safety, pension entitlements, unemployment protection, co-determination rights, tenure laws and many other items were implemented to a large extent in east Germany. There was not even a transition phase for the adoption of these standards. East German jobs bear nearly the same indirect wage costs as jobs in the west.

Most of the social transfers paid out in east Germany were replacement incomes in the sense discussed above which implied high floors on market wages. With these payments, the welfare state has emerged as the major competitor of east German industry in the labour markets, and has actually squeezed out east German employment. ${ }^{12}$

Table 2 reports an attempt to calculate the floor on east German wage costs resulting from the level of east German social assistance (minimum guaranteed state income) for alternative hourly 'effective wage rates' and for different types of families. We define the effective wage rate as the net income increase per hour if someone moves from welfare without work to a regular full-time job, and we take into account all taxes, contributions and transfers that apply in these two economic situations. The initial rows show, for the year 2000, the annual replacement income, the replacement wage rate, and the hourly wage cost to the employer that corresponds to assumed alter-

\footnotetext{
${ }^{12}$ Germany is currently aiming at welfare reforms that move away from replacement incomes towards wage supplements. However, the steps announced thus far are disappointingly lame.

(c) Blackwell Publishing Ltd 2003
} 
Table 2: Lower Bound on East German Wage as per cent of West German Wage for Alternative Effective Wage Rates and Family Situations as Implied by East German Tax-Transfer System, 2000

\begin{tabular}{|c|c|c|c|c|c|c|c|}
\hline & & $\begin{array}{l}\text { Effective } \\
\quad \text { Wage } \\
\text { per Hour } \\
\quad €\end{array}$ & Singles & $\begin{array}{l}\text { Couple, } \\
\text { No } \\
\text { Children }\end{array}$ & $\begin{array}{c}\text { Couple, } \\
1 \\
\text { Child }\end{array}$ & $\begin{array}{c}\text { Couple, } \\
2 \\
\text { Children }\end{array}$ & $\begin{array}{c}\text { Couple, } \\
3 \\
\text { Children }\end{array}$ \\
\hline $\begin{array}{l}\text { 1. Annual replacement } \\
\text { income east Germany }\end{array}$ & $€$ & 0 & 6,407 & 10,447 & 13,571 & 16,579 & 19,457 \\
\hline $\begin{array}{l}\text { 2. Replacement wage } \\
\text { rate east Germanyc }\end{array}$ & $€$ & & 3.77 & 6.15 & 7.98 & 9.75 & 11.45 \\
\hline $\begin{array}{l}\text { 3. East German hourly } \\
\text { wage cost to the } \\
\text { employer }^{d}\end{array}$ & $€$ & $\begin{array}{l}0 \\
2.5 \\
5.0\end{array}$ & $\begin{array}{r}5.71 \\
10.49 \\
16.89\end{array}$ & $\begin{array}{r}9.31 \\
13.10 \\
18.16\end{array}$ & $\begin{array}{l}10.62 \\
14.78 \\
20.08\end{array}$ & $\begin{array}{l}11.83 \\
16.37 \\
21.86\end{array}$ & $\begin{array}{l}12.92 \\
17.89 \\
23.63\end{array}$ \\
\hline $4 .=(3): 27.18^{e}$ & $\%$ & $\begin{array}{l}0 \\
2.5 \\
5.0\end{array}$ & $\begin{array}{l}21.00 \\
38.60 \\
62.10\end{array}$ & $\begin{array}{l}34.30 \\
48.20 \\
66.80\end{array}$ & $\begin{array}{l}39.10 \\
54.30 \\
73.90\end{array}$ & $\begin{array}{l}43.50 \\
60.20 \\
80.40\end{array}$ & $\begin{array}{l}47.50 \\
65.80 \\
86.90\end{array}$ \\
\hline
\end{tabular}

Source: Federal Statistical Office; calculations by the Ifo Institute.

Notes: ${ }^{a}$ Assumed increment of net income per hour from adopting an east German full-time job instead of receiving social assistance without working; ${ }^{b}$ social assistance per annum, including housing allowances; ${ }^{c}$ annual replacement income divided by 1700 hours per year; ${ }^{d}$ wage cost per hour without VAT that corresponds to a net-of-tax wage income sufficient to compensate for the replacement wage rate and alternative effective wage rates; ${ }^{e}$ average hourly wage cost to the employer in west Germany in euros; workers and employees in manufacturing, trade and banking; without value-added tax (= average wage cost per year divided by the average number of hours worked in west Germany [1645]).

native effective wage rates and the actual replacement wage rates in east Germany. The final three rows show the ratio of that wage cost to the actual average hourly wage cost to a west German employer (€27.18).

If welfare recipients are willing to accept jobs with net earnings equal to the replacement income, their effective wage rate is zero. In this case, the east German wage cost has to be at least 21.0 per cent for a single person and 47.5 per cent for a worker who is married with three children. If welfare recipients accept only jobs with an effective wage rate of $€ 5$ per hour, then the wage cost to the employer in east Germany would reach percentages of the west German average wage cost that range from 62.1 to 86.9 per cent.

Given this information, it is not surprising that the average east German hourly wage cost to the employer has risen rapidly after unification, and now stands at about 70 per cent of the respective west German figures. According to Table 2, 70 per cent corresponds to effective wage rates per hour of between $€ 2.50$ and $€ 5$. These are sufficiently small numbers to explain why 
there would be strong resistance in east Germany to wage cuts bringing the east German wage cost to a lower percentage of that of the west.

Unfortunately, however, the 70 per cent wage cost ratio is the central problem of the east German economy. The figure is high relative to east German productivity which, in the aggregate, is only 58 per cent of the west, and it is also high relative to other countries.

Figure 6 gives an overview of the development of the east German and other countries' labour cost (wage cost to the employer) per hour relative to the respective west German figure from before unification until 2001, measured at the prevailing exchange rates. The east German hourly labour cost was only 7 per cent of the west German level in 1989, but it quadrupled with the currency conversion, and in the following years it jumped to 64 per cent (1994) and then to 70 per cent (1999) of the western level (Sinn, 2001, p. 32). After unification, east German labour costs quickly surpassed those of Portugal, reaching those of Ireland in 1992. By 1995 east German hourly labour costs were as high as those in France and have since kept pace with France.

The main explanation for the rapid wage increase is that the initial wage negotiations were proxy negotiations that were carried out by people other than those who would have had to bear the consequences. ${ }^{13}$ The crucial wage negotiations took place in 1991, long before the privatization of the east German economy had even begun, and they specified a full equalization of union wages within a period of only five years. West German employers' associations contracted with west German trade unions over east German wages. There were no east German employers, and east German workers had no say. The west German negotiators were determined to adjust eastern wages as quickly as possible to the western level to eliminate the risk that low-wage competition by eastern firms, revitalized with fresh international capital and know-how, would reduce profits and jobs in the west.

While the proxy negotiations triggered off the wage adjustment, they cannot explain the persistence of high wages in east Germany to this day. Surprisingly, wages have remained high despite the fact that new entrepreneurs lured to the east by generous subsidies rapidly sought to break the contracts.

\footnotetext{
${ }^{13}$ It is sometimes argued that the effective revaluation that came with the one-to-one currency conversion enacted in 1990 was the major policy mistake behind this development. However, the one-to-one conversion was necessary to preserve the purchasing power of east German wages. Despite the fact that the exchange rate at which the GDR had been able to sell its merchandise in the west was $4.3: 1$, the east German mark had been more valuable to east German consumers at east German prices than the west German mark was at west German prices because the prices of consumer goods were much lower in the east than in the west. Thus there was no politically feasible way to avoid the one-to-one conversion. In terms of consumer goods, wages in the east were about one-third of the west before and after the currency conversion. Had that wage level been preserved until privatization was completed, the east German economy would have become competitive very quickly, and a second economic miracle in Germany might have taken place.
} 


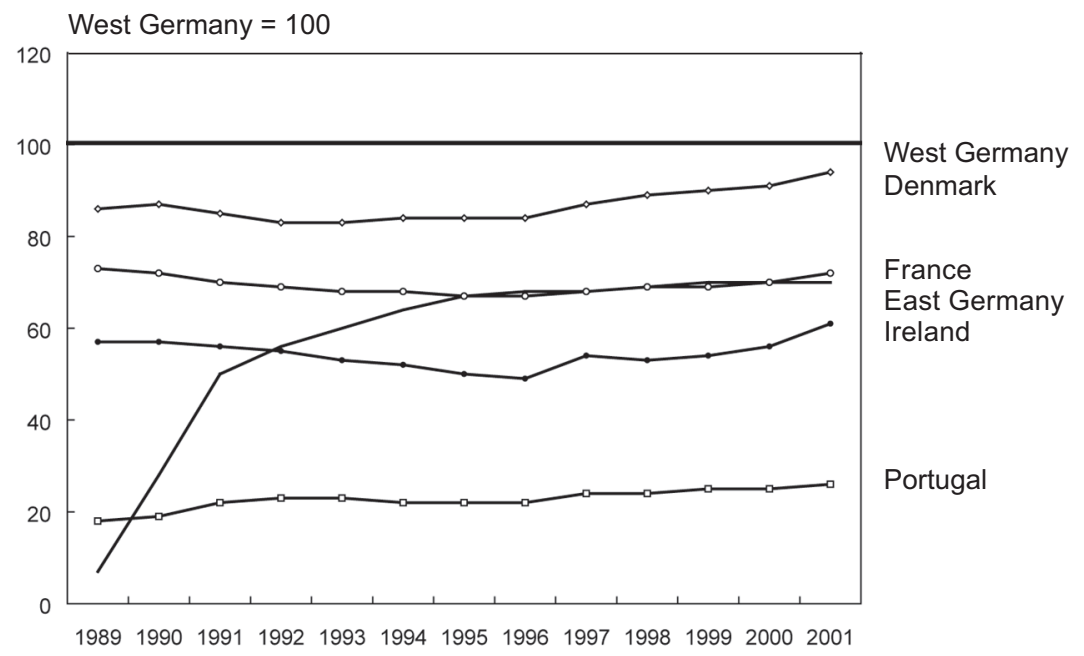

Figure 6: Hourly Industrial Labour Cost Relative to West German Costs

Sources: For Denmark, France, Ireland, Portugal and West Germany: Cologne Institute for Business Research, Hourly Labour Cost of Blue-collar Workers in Manufacturing, database. For East Germany and West Germany: Arbeitskreis 'Volkswirtschaftliche Gesamtrechnungen der Länder', Arbeitnehmerentgelte (Inland), 1991 bis 2001; Autorengemeinschaft des IAB, Der Arbeitsmarkt in den Jahren 2000 und 2001 sowie 2001 und 2002; calculations by the Ifo Institute.

Notes: The database of the Cologne Institute for Business Research is based on Eurostat's surveys of labour costs carried out in 1988, 1992, 1996 and 2000. The interpolations for 1993, 1994 and 1995 were made by the Ifo Institute.

Today, only 15 per cent of east German firms and no more than 45 per cent of the privately employed east German workforce is covered by union contracts. Nevertheless, wages have been unresponsive to mass unemployment. This persistence is undoubtedly due to the welfare state itself. For the reasons explained in Table 2, wages cannot be cut significantly below their current levels without violating the reservation wage constraint.

The consequences of the high wage strategy are well known. The east German economy collapsed immediately after unification, with 80 per cent of industrial jobs being destroyed, industrial output falling by more than 60 per cent and GDP falling by more than one-third. After this collapse there was a short-lived recovery until 1996, stimulated by an extremely generous investment subsidy programme which effectively eliminated the cost of capital, even pushing it to negative values. As soon as this programme was cancelled, the east German economy began to slump, and the gap between western and eastern GDP per capita has widened in every year since. Employment has been shrinking at an annual rate of nearly 2 per cent during this time, and mass unemployment has grown to dangerously high levels. Investment in 
equipment per person of working age which, under the investment subsidy programme, had peaked at 144 per cent of the western level, fell to only 88 per cent in 2002.

In the first decade after unification, the west German government transferred a net $€ 750$ billion to east Germany, a sum that was mostly financed by public borrowing. Currently, the annual transfer still amounts to about $€ 80$ billion, which corresponds to about 4.0 per cent of west German GDP. East Germany's current account deficit is about 45 per cent of its own GDP, with about three-quarters financed by public transfers and only one-quarter by private capital flows. However, a substantial part of the private capital flows are used to buy the bonds issued by the east German states with the consequence that the debt-GDP ratio of the east German states has already surpassed that of their western counterparts. This trend is not sustainable.

\section{Italian Mezzogiorno}

The east German situation parallels the Italian Mezzogiorno which has not caught up with the north, stagnating at a GDP per capita of about 60 per cent of northern Italy, roughly the same ratio as that for Germany. Unemployment in the Mezzogiorno is persistent, and permanent transfers from the north are necessary to compensate for the poor economic performance. Although the current account deficit is only 13 per cent of GDP rather than the German 45 per cent, the similarities are striking (Sinn and Westermann, 2001, p. 31), notably in wage harmonization brought about by the collective bargaining process (Attanasio and Padoa-Schioppa, 1991; Sinn and Westermann, 2001). ${ }^{14}$

That wages are too high becomes obvious when the unemployment situation is considered. In 2002 the unemployment rate in the north was as low as 4 per cent, but as high as 18 per cent in the south. More than 60 per cent of Italy's 2 million unemployed workers live in the southern regions of Italy and, since the 1970s, the gap in unemployment rates has been persistent (Bertola and Garibaldi, 2002). In addition to the high unemployment rate, the Mezzogiorno is dependent on governmental transfers which in 1988 amounted to 20 per cent of regional GDP. At that time transfers amounted to roughly $€ 40$ billion. Recently, Italian subsidies have declined, having partly been replaced by EU subsidies (Belke and Hebler, 2002, p. 315; Sinn and Westermann, 2001, pp. 34-5).

German and Italian policy mistakes should not be repeated at the European level. Social standards, social assistance, unemployment benefits and wages must continue to be considerably lower in the less-advanced countries than in the core areas during a long transition period, and until an adequate

\footnotetext{
${ }^{14}$ A regional wage differentiation was possible in the 1950 s and early 1960 s and has again been possible since 1999.
}

(C) Blackwell Publishing Ltd 2003 
capital stock has been accumulated. As to the wage proxy negotiations, they can be ruled out for the EU accession countries because negotiations there will take place between national trade unions and national employers. It is hard to imagine that they will come under pressure from the core countries. With respect to social standards and wage replacement incomes, however, the situation is different. The EU risks being pressurized by labour unions and employers' associations into imposing minimum social standards and welfare levels on the new member countries.

\section{Social Inclusion, EU Constitution and Migration: Lessons for Europe}

Unfortunately, the risk that the Italo-German development model will be extended to other EU members, old and new, will rise significantly if the draft Treaty Establishing a Constitution for Europe that the European Convention presented in June 2003 to the European Council is accepted. The problem lies in the proclamation of European citizenship (Article I 8), in combination with the prohibition of discrimination on the basis of national citizenship (Article I 4), the proclaimed goals of social protection and social cohesion (Article I 3 and I 13), the provision of extensive social inclusion rights (Article II 34), the setting of minimum social standards (Article I 13 in connection with Article III 104 ), as well as the co-ordination of Member States' social policies (Article I 14). All of these clauses were included in earlier EU Treaties and were implicit in the decisions of the European Court of Justice, but they are now to be elevated to the status of constitutional law. This new superior status would imply that they would supersede all existing European laws and treaties. In particular, it seems likely that the limitations of the so-called social inclusion principle that are currently in place would be eliminated, implying a social union for Europe.

The inclusion principle is currently interpreted to mean that an EU citizen who moves from one EU country to another in order to work is immediately and fully integrated into the social system of the host country. The immigrant pays taxes and social insurance contributions and, together with his family, is eligible for all state benefits available to domestic employees. An immigrant worker with a below-average income benefits from income redistribution via the welfare state just as a national does. Based on statistical information on past immigrants to Germany, the Ifo Institute calculated that net receipts per person, per year were approximately $€ 2,300$ in the first ten years. ${ }^{15}$ A family of four living in Germany for ten years would consequently receive an immigration premium of nearly $€ 100,000$.

15 Ifo calculations are based on a 'fiscal balance' of previous immigration to Germany and include social insurance, tax-financed social services and all state revenue and expenditure (Sinn et al., 2001, p. 27).

(C) Blackwell Publishing Ltd 2003 
Restricting the inclusion principle to working immigrants has limited this kind of immigration subsidy. Those who imigrate for reasons other than employment receive no welfare benefits apart from emergency health care. However, the proposals of the European Convention could - if taken at face value and not curbed by the usual forms of horse-trading - mean that the inclusion principle will apply to all migrants from EU countries, including pensioners and other people who are not included in the discrimination clause in connection with EU citizenship in the sense of full social inclusion. Courts have already rendered generous rulings on the inclusion principle based on the present EU Treaties.

Welfare migration would be the constitutional right of every EU citizen, amplifying current problems with the inclusion principle. If having work is no longer required before migrating, a major barrier to migration will be removed. Large numbers of poor people would have the incentive to move from eastern European countries to the west. The transitional, post-enlargement regulations will help only temporarily. The financial burdens that already plague western European welfare states will become so enormous that radical cuts will be inevitable.

Traditional social welfare states could not be maintained under these circumstances because governments will try to stem migration by reducing social benefits. Since highly mobile individuals are free to choose where to migrate to, host governments would compete to deter them, triggering a race to the bottom in welfare provision.

International harmonization of social replacement incomes at the EU level could prevent this, and in fact the draft Constitution contains sufficient references to social protection and cohesion of Europe to encourage such policies.

But this would lead to serious problems since social standards acceptable to the more developed countries would produce mass unemployment as explained above. As is shown in Figure 7, in all eastern European countries net wage income is less than 30 per cent of west German social assistance, and even the present EU contains Portuguese, Greek and Spanish regions where net wage income is less than half the German welfare level. Harmonization of social assistance at a level still acceptable to mature western European economies would lead to the de-industrialization of whole regions in southern and eastern Europe and could inhibit their economic development.

The economic pain of the less developed countries could then only be eased by intergovernmental fiscal transfers from more developed regions. The cohesion principle in the draft Constitution would permit such a policy. The Italo-German figures of public transfers in the order of 20-30 per cent of the south Italian and east German GDPs indicate the orders of magnitude involved. 


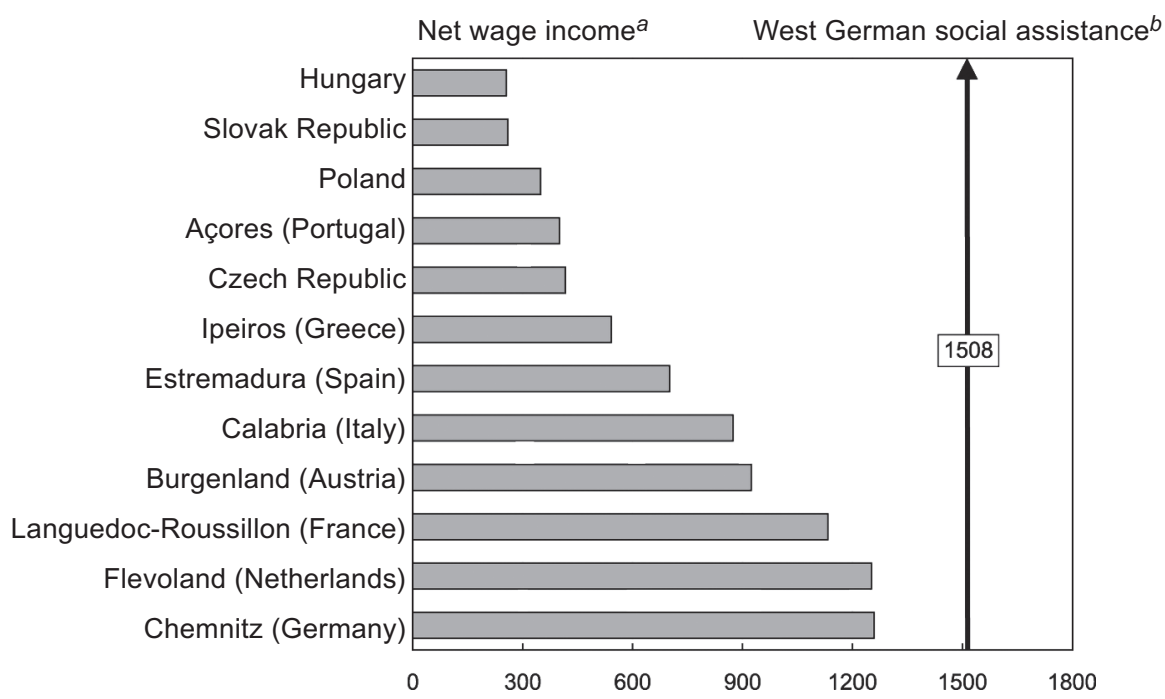

Figure 7: Net Wages and Social Assistance Compared (Monthly Rates, 2000) Sources: OECD (2002); Eurostat, Statistics in Focus, 3/2001 and 4/2001; Sinn et al. (2002).

Notes: ${ }^{a}$ One earner couple with two children, average production worker; ${ }^{b}$ Couple with two children.

There is a growing consensus that the EU institutional structure should be equipped to deal with the risk of race-to-the-bottom tensions in the field of welfare policy (Bertola et al., 2001, pp. 89-96). In order to prevent a race to the bottom, it has been proposed that an EU transfer system to guarantee a minimum welfare level to all citizens be established. For Bertola et al. (2001, pp. 105-7) some interjurisdictional redistribution and the resulting unemployment is hardly avoidable given the different income levels of EU countries. Hence, minimum welfare transfers should be co-financed by the EU budget. When targeting minimum assistance levels, policy-makers should bear in mind the trade-off between welfare migration and employment. In order to prevent welfare migration, the minimum standard needs to be specified in absolute terms rather than in relation to local incomes. Cost-of-living differentials should, however, be taken into account by the definition of country-specific and region-specific minimum levels of welfare provision. On the other hand, uniform absolute welfare standards would have negative employment effects in relatively poor countries or regions, since they increase the reservation wage. In order not to reduce employment, minimum assistance levels should be specified on a relative basis, as a proportion of local average earnings, and they would be much lower in Portugal and Poland than in Germany or the United Kingdom. Guided by the extent of labour mobility, a compromise be- 
tween fixing minimum assistance levels in absolute EU-wide terms or targeting them in relation to local average earnings should be sought.

We do not agree with this proposal because a partial harmonization of wage replacement incomes means a partial disaster of the type we observe in the Italian and German 'Mezzogiornos'. Europe cannot afford more mass unemployment, let alone mass unemployment concentrated in its backward regions. Harmonization of replacement incomes only makes sense in the far distant future when the economic convergence process has come to an end.

\section{Selectively Delayed Integration and the EU Constitution}

As an alternative to a harmonization of replacement incomes, the Expert Council of the German Ministry of Finance (2001), the Ifo Institute (Sinn et al., 2001) and recently the European Economic Advisory Group (2003) have proposed the 'principle of selectively delayed integration' of immigrants into the welfare state. This is a modified version of the home country principle for welfare benefits (see also Richter, 2002; Sinn, 2002). Immigrants pay taxes and social security contributions as resident citizens and, in return, obtain free access to the public infrastructure, police, legal protection and free education; they also receive undiminished benefits from the contribution-financed social system. But certain tax-financed benefits like social assistance, rent subsidies and public housing would not be available during some initial period of residence. The range of benefit restrictions would be balanced so that the present value of the benefits the immigrants receive is equal to the present value of the taxes and contributions they pay. The principle is that any EU citizen can migrate and work freely, but would receive no 'gifts' from the host country. As stated above, empirically the excess of benefits over taxes and contributions amounted to $€ 2300$ per person per year during the first ten years after immigration to Germany, or nearly $€ 100,000$ in total for a family of four. The principle of selectively delayed integration would therefore have significant economic consequences.

Even with delayed integration into the welfare state, there will be migration, but it will be driven by genuine market signals rather than the artificial incentives set by the welfare state. With a single stroke, the welfare policy of the national governments could be freed from having to take into account the migration processes it itself causes, and the forces eroding the welfare state would be tamed. The race to the bottom would not take place. The protective harmonization of social replacement incomes would be unnecessary and, what is more, the economic forces that bring about social convergence in Europe would be strengthened. 
The introduction of the principle of delayed integration would be particularly timely in the light of the imminent eastern enlargement of the EU, because the welfare gaps in these countries are particularly large and substantial migration flows are expected. The EU has already agreed on a seven-year transition period, during which there will be quantity constraints on migration and migrants will be selected according to specific criteria. This solution implies a postponement of some of the basic liberties granted in the Treaty of Rome (Sinn, 2003, ch. 3). It is a severe intervention in the market process which will lead to large welfare losses due to inefficiently low migration volumes and a distorted selection of migrants relative to what a market solution would have brought about. The principle of delayed integration is the better alternative.

When the principle of selectively delayed integration into the welfare state is applied, economic and social convergence brought about by the forces of private and governmental competition will be fast and efficient. The social objectives of Europe can be reached without enormous economic costs in terms of unemployment and distorted migration decisions that otherwise would have to be borne. However, in order for this solution to be achieved, the nondiscrimination clause in Article 6 of the draft Constitution will have to be abandoned or at least restricted to issues other than social transfers.

There is an important example of a partial implementation of the home country principle that is similar to the idea of delayed integration. Swiss cities provide certain kinds of welfare assistance to citizens born in the city even if they live elsewhere. It would be wise for the EU to write the new Constitution in a way that makes it possible to follow this example, and to pave the way for the principle of selectively delayed integration.

\section{Conclusions}

Europe is converging much more quickly than could have been expected 20 years ago. The creation of the common market for goods and services and the completion of a single capital market by means of a common currency have levelled the playing field. Investment and other forces of growth have been shifting to the previously disadvantaged countries, and the old core countries have lost their advantages of size and location. Economic convergence automatically brings about social convergence. Wages are becoming more equal, and the countries whose economies are catching up can also afford steady improvements in their social standards. The forces of the market and systems competition will no doubt bring about rapid social convergence.

Beyond the creation of common capital, goods and labour markets, as well as international transfers for the purpose of supporting infrastructure invest- 
ment, the EU can do very little to improve or speed up the convergence process. In particular, there is no need for social policies at the EU level. Such policies incur the risk of distorting migration decisions and slowing down capital flows to the disadvantaged regions. The examples of east Germany and the Italian Mezzogiorno highlight the economic dilemmas that would result. Premature harmonization of social standards is a recipe for stagnation in Europe.

It is true that the welfare state will be threatened by the free migration of people in Europe. The race to the bottom is a serious risk. However, to contain this risk, neither harmonization of welfare payments nor constraints on migration are needed. The adoption of a weak version of the home country principle for intra-EU migration, which we call the principle of selectively delayed integration, is the better alternative. Adhering to this principle will ensure a maximal convergence speed and safeguard the European welfare state despite the increasing mobility of people. The fathers and mothers of the European Constitution should think about the economic consequences of their recommendations, as sometimes ideals will not materialize when they are enforced by binding legal provisions.

\section{Correspondence:}

Hans-Werner Sinn and Wolfgang Ochel

Ifo Institute for Economic Research

Poschingerstr. 5

81679 Munich, Germany

email: sinn@ifo.de ochel@ifo.de

\section{References}

Attanasio, O. P. and Padoa-Schioppa, F. (1991) 'Regional Inequalities, Migration and Mismatch in Italy, 1960-86'. In Padoa-Schioppa, F. (ed.) Mismatch and Labour Mobility (Cambridge: Cambridge University Press).

Barro, R.J. and Sala-i-Martin, X. (1995) Economic Growth (New York: McGrawHill).

Bean, C., Bentolila, S., Bertola, G. and Dolado, J. (1998) Social Europe: One for All? (London: CEPR).

Belke, A. and Hebler, M. (2002) 'Towards a European Social Union: Impacts on Labor Markets in Acceding Countries'. Constitutional Political Economy, Vol. 13, No. 4, pp. 313-35.

Bertola, G. and Garibaldi, P. (2002) 'The Structure and History of Italian Unemployment'. CESifo Conference on 'Unemployment in Europe: Reasons and Remedies', Munich. 
Bertola, G., Jimeno, J.F., Marimon, R. and Pissarides, C. (2001) 'EU Welfare Systems and Labor Markets: Diverse in the Past, Integrated in the Future?'. In Bertola, G., Boeri, T. and Nicoletti, G. (eds) Welfare and Employment in a United Europe (Cambridge, MA/London: MIT Press).

Boss, A. (2001) Sozialhilfe, Lohnabstand und Mindestarbeitslosigkeit, Kieler Arbeitspapier 1075, Institut für Weltwirtschaft, Kiel.

Closa, C. (1998) 'Some Sceptical Reflections on EU Citizenship as a Basis for a New Social Contract'. In Rhodes, M. and Mény, Y. (eds) The Future of European Welfare: A New Social Contract? (Basingstoke: Macmillan).

Commission of the European Communities (1994) 'European Social Policy: A Way Forward for the Union: A White Paper'. COM (94)333, Luxembourg.

Constant, A. and Massey, D.S. (2002) 'Return Migration by German Guestworkers: Neoclassical Versus New Economic Theories'. International Migration, Vol. 40, No. 4, pp. 5-38.

European Economic Advisory Group (2003) Report on the European Economy 2003 (Munich: CESifo).

Expert Council of the German Ministry of Finance (2001) 'Freizügigkeit und soziale Sicherung in Europa'. Schriftenreihe des BMF 69, Bonn.

Feldmann, H. (1999) 'Zehn Jahre EU-Sozialcharta'. Wirtschaftsdienst, No. 11, pp. 670-76.

Kleinman, M. (2002) A European Welfare State?, European Union Social Policy in Context (Basingstoke/New York: Palgrave).

Nierhaus, W. (1999) 'Höhere Rentenanpassung in Ostdeutschland erforderlich?'. Ifo Schnelldienst, Vol. 52, No. 19, pp. 20-4.

OECD (2002) Taxing Wages 2000-2001 (Paris: OECD).

Richter, W.F. (2002) 'Social Security and Taxation of Labour Subject to Subsidiarity and Freedom of Movement'. Swedish Economic Policy Review, Vol. 9, No. 1, pp. $47-74$.

Rodriguez, F. and Rodrik, D. (1999) 'Trade Policy and Economic Growth: A Skeptic's Guide to the Cross-national Evidence'. NBER Working Paper 7081.

Scharpf, F.W. (2002) 'The European Social Model: Coping with the Challenges of Diversity'. Journal of Common Market Studies, Vol. 40, No. 4, pp. 645-870.

Schmidt, C.M. (1994) 'The Country of Origin, Family Structure and Return Migration of Germany's Guest-Workers'.DIW Vierteljahreshefte zur Wirtschaftsforschung, No. $1 / 2$, pp. 119-25.

Schröder, C. (2000) 'Industrielle Arbeitskosten im internationalen Vergleich'. Iwtrends, Vol. 27, No. 3, pp. 77-91.

Sinn, G. and Sinn, H-W. (1992) Jumpstart. Economic Aspects of German Unification (Cambridge, MA: MIT Press).

Sinn, H-W. (2001) ‘Social Dumping in the Transformation Process?'. CESifo Working Paper No. 508.

Sinn, H-W. (2002) 'EU Enlargement and the Future of the Welfare State'. Stevenson Lectures on Citizenship, Scottish Journal of Public Economy, Vol. 49, No. 1, pp. $104-15$.

(c) Blackwell Publishing Ltd 2003 
Sinn, H-W. (2003) The New Systems Competition (Oxford/Malden, MA:Blackwell). Sinn, H-W. and Westermann, F. (2001) 'Two Mezzogiornos'. Rivista di Diritto Finanziario e Scienza della Finanze, Vol. 60, No. 1, pp. 29-54.

Sinn, H-W., Holzner, C., Meister, W., Ochel, W. and Werding, M. (2002) 'Aktivierende Sozialhilfe, Ein Weg zu mehr Wachstum und Beschäftigung'. Ifo Schnelldienst, Vol. 55, No. 9, pp. 3-52.

Sinn, H-W., Flaig, G., Werding, M., Munz, S., Düll, N. and Hofmann, H., with Hänlein, A., Kruse, J., Reinhard, H-J. and Schulte, B. (2001) EU-Erweiterung und Arbeitskräftemigration: Wege zu einer schrittweisen Annäherung der Arbeitsmärkte, Ifo Institute for Economic Research, Munich. 